\title{
ANALISIS KEMAMPUAN PEMECAHAN MASALAH MATEMATIS SISWA SMP KELAS VII PADA MATERI ARITMETIKA SOSIAL
}

\author{
Rizky Restiani Fatmala ${ }^{1}$, Ratna Sariningsih $^{2}$, Luvy Sylviana Zhanty ${ }^{\mathbf{3}}$ \\ 1,2,3 IKIP Siliwangi, J1. Terusan Jendral Sudirman, Cimahi tengah, Kota Cimahi, Jawa Barat \\ kiki20460@gmail.com
}

\begin{abstract}
The research aims to analyse students ' mathematical skills. The research approach used is qualitative with a descriptive analytical method so that it gained an overview of the ability to solve students ' mathematical problems. The instrument used is a mathematical problem-solving capability test, interview guidelines, and polls that have been validated. Interview guidelines for obtaining information about the mistakes that students do. Poll to learn about the students ' interest in mathematics. The subject of research is grade VIII students in one of the SMP in Purwakarta district which is as many as 30 people. Based on research that the ability to solve the mathematical problem of the students is relatively low. From the data obtained 36 students, it can be concluded that students' problem solving abilities are still relatively low. Many students are still mistaken in indicators of understanding a problem, planning a solution, carrying out a solution, and checking answers. This is because students are still not accustomed to working on problem solving problems so students have difficulty in understanding each of these problems, many students are wrong in doing problem solving calculations, besides the average student does not re-check the answers that have been made. Students need to be often trained to work on problem solving problems so that their problem-solving abilities can improve, students are expected to be more careful in understanding problems, determining answers, and re-checking the answers they have made.
\end{abstract}

Keywords: Troubleshooting, Error Analysis

\begin{abstract}
Abstrak
Penelitian ini bertujuan untuk menganalis kemampuan pemecahan matematis siswa. Pendekatan penelitian yang digunakan adalah kualitatif dengan metode deskriptif analitis sehingga diperoleh gambaran tentang kemampuan pemecahan masalah matematis siswa. Instrumen yang digunakan adalah tes kemampuan pemecahan masalah matematis, pedoman wawancara, dan angket yang telah dilakukan validasi. Pedoman wawancara untuk memperoleh informasi tentang kesalahan yang dilakukan siswa. Angket untuk mengetahui minat siswa terhadap matematika. Subjek penelitian adalah siswa kelas VIII pada salah satu SMP di Kabupaten Purwakarta yang sebanyak 30 orang. Berdasarkan penelitian yang telah dilakukan bahwa kemampuan pemecahan masalah matematis siswa tersebut tergolong rendah. dari data yang didapat 36 siswa, dapat disimpulkan bahwa kemampuan pemecahan masalah siswa masih tergolong rendah. Banyak siswa masih keliru dalam indikator memahami masalah, merencanakan penyelesaian, melaksanakan penyelesaian, dan memeriksa kembali jawaban. Hal tersebut disebabkan karena siswa masih belum terbiasa mengerjakan soal-soal pemecahan masalah sehingga siswa mendapatkan kesulitan dalam memahami setiap soal tersebut, siswa banyak yang keliru dalam melakukan perhitungan penyelesaian masalah, selain itu siswa rata-rata tidak memeriksa kembali jawaban yang telah dibuat. Siswa perlu sering dilatih untuk mengerjakan soal-soal pemecahan masalah agar kemampuan pemecahan masalah mereka bisa meningkat, siswa diharapkan akan lebih teliti dalam memahami permasalahan, menentukan jawaban, serta memeriksa kembali jawaban yang telah dibuatnya.
\end{abstract}

Kata Kunci: Pemecahan Masalah,Analisis Kesalahan

\section{PENDAHULUAN}

Matematika merupakan salah satu mata pelajaran yang sangat penting dan matematika di pelajari di semua jenjang sekolah bahkan di perguruan tinggi sekalipun, matematika harus di ajarkan dari sejak usia dini (Bernard et.al., 2019; Akbar, 2018; Bungsu, 2019; Rahmawati, 2019; Sugandi \& Akbar, 2019) dikarenakan untuk memperkuat dasar-dasar ilmu matematikanya semakin dipelajari sejak usia dini semakin kuat dalam pemahaman konsep matematikanya hal ini sejalan dengan Hidayat dkk., (2017). 
Tingkat kemampuan berpikir siswa dalam pembelajaran matematika terbagi menjadi dua yaitu kemampuan berpikir tingkat tinggi (High Order Thinking Skill /HOTS) dan kemampuan berpikir tingkat rendah (Low Order Thinking Skills) (Insani, \& Akbar, 2019), salah satu kemampuan penting yang termasuk dalam HOTS adalah kemampuan Pemecahan Masalah, Kemampuan Pemecahan masalah menuntut siswa aktif dan maksimal dalam melakukan eksplorasi, observasi, eksperimen, dan investigasi. Ulvah (Nuryana \& Rosyana, 2019) menyatakan, siswa yang lebih aktif dalam kegiatan pembelajaran cenderung memiliki kemampuan pemecahan masalah yang lebih baik daripada siswa yang tidak terlibat dalam kegiatan pembelajaran. Melalui aktivitas pembelajaran yang baik siswa tidak akan merasa jenuh dalam belajar, maka dari itu kemampuan pemecahan masalah siswapun berkembang. Sejalan dengan itu, Hendriana \& Sumarmo (Nuryana \& Rosyana, 2019) mengatakan, melalui kemampuan pemecahan masalah diharapkan siswa mampu menemukan konsep matematika dengan sendirinya. Kemudian Fitria (Nuryana \& Rosyana, 2019) mengatakan, memecahkan masalah matematika dapat dipandang sebagai proses dimana siswa menemukan aturan-aturan yang telah dipelajari sebelumnya, digunakan untuk memecahkan masalah yang baru. Memecahkan masalah tidak hanya sekedar menerapkan aturan-aturan yang diketahui, akan tetapi juga menghasilkan pelajaran baru dan menemukan baru (Timutius, 2018; Siswanto, 2018).

Dalam memecahkan suatu masalah merupakan salah satu kemampuan dasar matematis yang harus dikuasai siswa sekolah menengah. Menurut Sugandi (2013), bahwa pembelajaran yang lebih menekankan pada pemecahan masalah sangat erat kaitannya dengan pencapaian prestasi siwa yang tinggi. Pentingnya kemampuan pemecahan masalah juga dapat dilihat dari hampir setiap standar kopetensi dan kompetensi dasar terdapat aspek kemampuan pemecahan masalah. Namun pada kenyataanya tidak semua siswa mampu memecahkan masalah dengan baik. Hal ini sejalan dengan pernyataan Sugandi (2013) menyatakan bahwa hasil belajar pemecaha masalah matematik siswa pada saat ini masih rendah atau dengan kata lain proses pemecahan masalah masih dianggap sulit oleh para siswa. Maka dari itu pemebelajaran dengan menggunakan pemecahan masalah ini sangat penting untuk siswa tingkat SMP karena memudahkan dalam melakukan berpikir secara logis dalam pembelajarannya hal ini sejalan dengan apa yang dikatakan oleh nuryana dan rosyana (2019) pemecahan masalah merupakan salah satu solusi dalam meningkatkan pembelajaran di sekolah.

Pada penelitian sebelumnyapun menunjukan bahwa hasil dari kemampuan pemecahan masalah matematis menunjukan bahwa 97,06 \% siswa tidak dapat mengerjakan soal Putra, Thahiram, Ganiati, \& Nuryana, (2018) Hasil penelitian sebelumnya menunjukkan bahwa masih ada 5 siswa melakukan kesalahan pemahaman, sebanyak 13 siswa melakukan kesalahan trans-formasi, sebanyak 29 siswa masih melakukan kesalahan pada indikator keterampilan, dan sebanyak 33 siswa melakukan kesalahan pada indikator menyimpulkan, dapat dinyatakan bahwa kemampuan pemecahan masalah siswa pada salah satu sekolah SMPN Kabupaten Purwakarta masih tergolong rendah maka dari itu perlu dilakukan upaya peningkatan. Berdasarkan pemaparan diatas, maka peneliti tertarik melakukan sebuah penelitian 
Analisis Kemampuan Pemecahan Masalah Matematis Siswa Smp Kelas VII Pada Materi Aritmetika Sosial, Rizky Restiani

dengan judul Analisis Kemapuan Pemecahan Masalah Kelas VII SMP Dengan Materi Aritmatika Sosial.

\section{METODE}

Penelitian ini menggunakan pendekatan kualitatif dengan metode deskriptif untuk memperoleh gambaran tentang kemampuan pemecahan masalah matematis siswa. Subjek penelitian adalah 36 siswa kelas VII di salah satu SMP di Kabupaten Purwakarta. Instrumen penelitian terdiri dari tes kemampuan pemecahan masalah matematis, pedoman wawancara, dan angket yang telah dilakukan /validasi. Tahap penelitian meliputi perencanaan, pelaksanaan, dan pengamatan. Kegiatan pada tahap perencanaan yaitu menyusun instrumen dan melakukan validasi. Kegiatan pada tahap pelaksanaan yaitu memberikan tes kemampuan pemecahan masalah matematis mengenai materi aritmetika sosial pada siswa. Kegiatan pada tahap pengamatan yaitu menganalisis kesalahan siswa dalam menyelesaikan soal-soal kemampuan pemecahan masalah matematis. Siswa memiliki kemampuan pemecahan masalah dengan proses dan cara yang baik maka dapat menyelesaikan soal-soal dengan benar. Menurut Nuryana \& Rosyana (2019), soal yang diujikan pada siswa mesti memenuhi indikator kemampuan yang telah ditetapkan. Soal uang diajukan hanya satu soal tapi dengan memenuhi keempat tahapatan, pertama dengan indikator pemahaman dimana siswa membuat model matematika dalam soal cerita atau dalam bentuk gambar. Kedua dengan indikator transformasi dimana merencanakan penyelesaian masalah sesuai dengan rencana. Ketiga dengan indikator keterampilan proses. Dan keempat dengan indikator penyimpulan dimana siswa dapat menyimpulkan dari suatu persoalaan tersebut. Skor ideal dari keseluruhan soal adalah 16.

Data skor pemecahan masalah matematis siswa dianalisis menggunakan rumus persentase, sebagai berikut: $\quad$ Nilai $=\frac{\text { Skor Siswa }}{\text { Skor Ideal }} \times 100 \%$

Kriteria kemampuan pemecahan masalah matematis siswa dikategorikan seperti pada Tabel 1 berikut.

Tabel 1.

Kriteria Penilaian Pemecahan Masalah

\begin{tabular}{|c|c|}
\hline Nilai (\%) & Kriteria \\
\hline $0<\mathrm{x} \leq 40$ & Sangat Rendah \\
\hline $40<\mathrm{x} \leq 50$ & Rendah \\
\hline $50<\mathrm{x} \leq 70$ & Sedang \\
\hline $70<\mathrm{x} \leq 90$ & Tinggi \\
\hline $90<\mathrm{x} \leq 100$ & Sangat tinggi \\
\hline
\end{tabular}

Pada Tabel 1 terlihat bahwa kriteria kemampuan pemecahan masalah matematis siswa dikategorikan menjadi lima tingkat, yaitu sangat tinggi, tinggi, sedang, rendah, dan sangat rendah. Jawaban tes kemampuan pemecahan masalah matematis masing-masing siswa dinilai dan dikelompokkan menurut kriteria tersebut. Kemudian dilakukan analisis untuk melihat kesalahan siswa dalam menyelesaikan soal-soal. 


\section{HASIL}

Penelitian ini dilakukan untuk memperoleh gambaran dan menganalisis kemampuan pemecahan masalah matematis siswa melalui penyelesaian soal-soal mengenai aritmetika sosial. Indikator yang menjadi dasar penilaian siswa adalah kesesuaian jawaban siswa dengan langkah-langkah dalam pemecahan masalah yaitu Memahami Masalah, Merencanakan Penyelesaian, Melaksanakan Penyelesaian, dan Memeriksa Kembali. (Akbar, 2019; Hendriana, Rohaeti, Sumarmo, 2017)

Pada Tabel 2 berikut ini ditampilkan rekapitulasi nilai siswa setelah mengerjakan soal-soal kemampuan pemecahan masalah matematis.

\section{Tabel 2.}

Rekapitulasi Nilai Siswa Beserta Analisis Kesalahan

\begin{tabular}{|c|c|c|c|c|c|}
\hline Skor & Nilai & Kriteria & $\begin{array}{c}\text { Jumlah } \\
\text { siswa }\end{array}$ & Js \% & Analilisi Kesalahan \\
\hline 16 & $100 \%$ & Sangat tinggi & 1 & $2,77 \%$ & $\begin{array}{l}\text { Siswa sudah tepat dalam menjawab soal } \\
\text { dan melakukan pemeriksaan jawaban } \\
\text { kembali }\end{array}$ \\
\hline 15 & $\begin{array}{l}93,75 \\
\%\end{array}$ & & 1 & $2,77 \%$ & $\begin{array}{l}\text { Siswa dapat menjawab soal akan tetapi } \\
\text { tidak memodelkan matematikanya }\end{array}$ \\
\hline 14 & $87.5 \%$ & \multirow{3}{*}{ Tinggi } & 4 & $11.11 \%$ & Siswa tidak menghitung jumlah lusinnya \\
\hline 13 & $75 \%$ & & 4 & $11.11 \%$ & $\begin{array}{l}\text { Siswa tidak dapat menjumlah lusin dan } \\
\text { harganya }\end{array}$ \\
\hline 12 & $81.25 \%$ & & 0 & 0 & Tidak ada siswa yang memperoleh skor 12 \\
\hline 11 & $62.5 \%$ & \multirow{3}{*}{ Sedang } & 3 & $8.33 \%$ & $\begin{array}{l}\text { Siswa tidak bisa menjawab operasi pecahan } \\
\text { campuran ke operasi pecahan biasa }\end{array}$ \\
\hline 10 & $68.75 \%$ & & 4 & $11.11 \%$ & $\begin{array}{l}\text { Siswa hanya menjawab harga jual dan } \\
\text { keuntungan }\end{array}$ \\
\hline 9 & $56.25 \%$ & & 4 & $11.11 \%$ & Siswa hanya bisa menjawab \\
\hline 8 & $50 \%$ & \multirow[b]{2}{*}{ Rendah } & 0 & $0 \%$ & Tidak ada siswa yang memperoleh skor 8 \\
\hline 7 & $43.75 \%$ & & 7 & $19.44 \%$ & $\begin{array}{l}\text { Siswa hanya bisa menjawab tentang lusin } \\
\text { dan harganya saja }\end{array}$ \\
\hline 6 & $37.5 \%$ & \multirow{6}{*}{ Sangat rendah } & 0 & $0 \%$ & Tidak ada siswa yang memperoleh skor 6 \\
\hline 5 & $31.25 \%$ & & 2 & $5.55 \%$ & $\begin{array}{l}\text { Siswa bisa memodelkan matematika dan } \\
\text { lusin }\end{array}$ \\
\hline 4 & $25 \%$ & & 4 & $11.11 \%$ & Siswa hanya memodelkan matematika saja \\
\hline 3 & $18.75 \%$ & & 0 & $0 \%$ & Tidak ada siswa yang memperoleh skor 6 \\
\hline 2 & $12.5 \%$ & & 1 & $2.77 \%$ & Siswa hanya menulis apa yang di tanyakan \\
\hline 1 & $6.25 \%$ & & 1 & $2.77 \%$ & Siswa Hanya menulis soal kembali \\
\hline
\end{tabular}

Pada Tabel 2 disajikan rincian skor dari 1-16 yang merupakan penjabaran atau gambaran dari skor satu soal namun mencakupi keempat indikator yang masing-masing indikator memiliki skor maksimal 4 sehingga skor tertinggi siswa dalam menjawab soal tersebut adalah 16. Untuk memperoleh informasi singkat dan data tentang kriteria kemampuan pemecahan masalah matematis beserta banyak siswa disajikan pada Tabel 3 berikut ini.

Tabel 3.

Kriteria Kemampuan Pemecahan Masalah Matematis Siswa

\begin{tabular}{|c|c|c|}
\hline Kriteria & Banyak Siswa & Persentase \\
\hline Sangat tinggi & 2 & $5,56 \%$ \\
\hline
\end{tabular}


Analisis Kemampuan Pemecahan Masalah Matematis Siswa Smp Kelas VII Pada Materi Aritmetika Sosial, Rizky Restiani Fatmala, Ratna Sariningsih, Luvy Sylviana Zhanty

\begin{tabular}{|c|c|c|}
\hline Tinggi & 8 & $22,22 \%$ \\
\hline Sedang & 11 & $30,56 \%$ \\
\hline Rendah & 7 & $19.44 \%$ \\
\hline Sangat rendah & 8 & $22,22 \%$ \\
\hline Jumlah & 36 & $100 \%$ \\
\hline
\end{tabular}

Berdasarkan Tabel 3 data yang di dapat dari 36 siswa sebanyak 2 siswa $(5,56 \%)$ memiliki kemampuan pemecahan masalah dengan kriteria sangat tinggi, sebanyak 8 siswa $(22,22 \%)$ dengan kriteria tinggi, sebanyak 11 siswa (30,56\%) dengan kriteria sedang, serta sebanyak 7 siswa (19.44\%) dengan kriteria rendah, dan sebanyak 8 siswa $(22,22 \%)$ memiliki kemampuan pemecahan masalah dengan kriteria sangat rendah seperti data pada Tabel 3 ini. Berdasarkan data tabel 3 diatas masih banyak siswa tergolong dalam kemampuan rendah dan sangat rendah pada pemecahan masalah di karenakan siswa tidak dapat memodelkan matematika dan tidak dapat menghitung keuntungan, hal ini sejalan yang telah di lakukan penelitian oleh widodo (2013) bahwa masih rendahnya kemampuan pemecahan masalah matematis difaktorkan belum terbiasanya siswa diberikan soal-soal yang non rutin dan bergantung pada temannya dalam menyelesaikan persoalanya.

Untuk mengetahui kesalahan siswa dalam menyelesaikan soal-soal kemampuan pemecahan masalah matematis, berikut ini ditampilkan soal kemampuan pemecahan masalah satu soal namun mencakup empat indikator dan beserta perwakilan jawaban siswa yang salah. Berikut dibawah ini adalah soal nya.

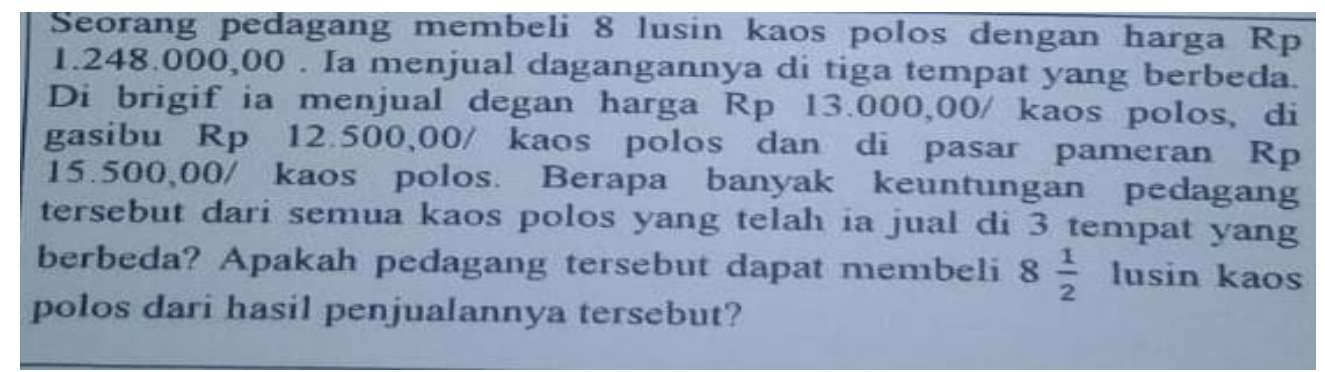

Gambar 1. Soal kemampuan pemecahan masalah matematis aritmetika sosial kelas VII Analisis Kemapuan Pemecahan Masalah Kelas VII SMP Dengan Materi Aritmatika Sosial Analasis Kesalahan Jawaban Siswa Pada Tahap Pemahaman (Memahami masalah)

Banyak siswa yang melakukan kesalahan paa tahap pemahaman, berikut ditampilkan salah satu jawaban siswa pada tahap pemahaman sehingga siswa tersebut memperoleh skor nol. 


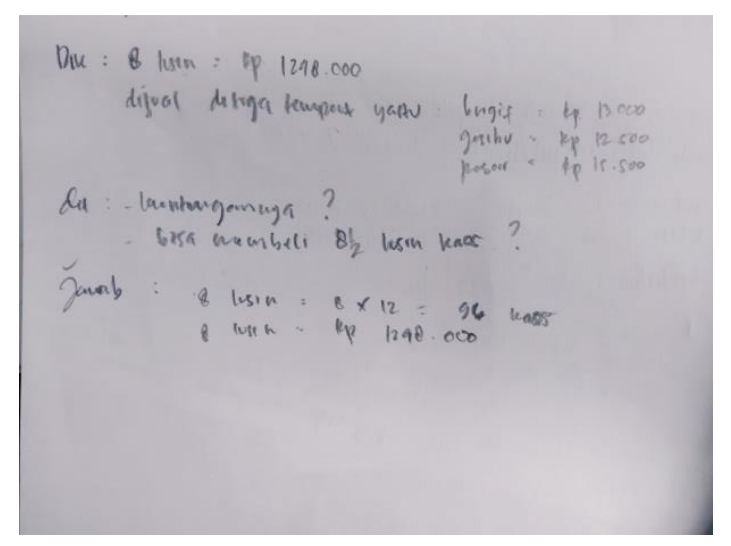

Gambar 2. Kesalahan Jawaban Siswa pada Tahap Pemahaman

Pada gambar 2 terlihat bahwa siswa sudah mengerti pertanyaan pada soal, tetapi siswa tersebut belum memahami cara menyelesaikan soal. Siswa tidak dapat menentukan model matematika. Dapat dilihat pada gambar 1, siswa hanya dapat mengerjakan sampai dengan diketahui dan ditanyakan saja. Selain itu, berdasarkan wawancara siswa memang kurang mengerti dan memahami materi dari awal siswa tidak bisa menjawab dan mengalami kesulitan pada saat memahami dan mengerjakan soal tersebut. Berdasarkan angket yang diperoleh juga pada saat siswa tersebut tidak bisa menjawab soal, siswa hanya berdiam saja, tidak ada usaha dan juga tidak ada keinginan untuk menjawab soal tersebut dan memang pada dasarnya siswa tersebut memang tidak menyukai pelajaran matematika karena ia beranggapan bahwa matematika itu sulit dan menakutkan. Maka dari itu, minat belajar matematika juga sangat penting dan siswa untuk dapat mengerjakan soal.

\section{Analisis Kesalahan Jawaban Siswa pada Tahap Transformasi (Merencanakan penyelesaian)}

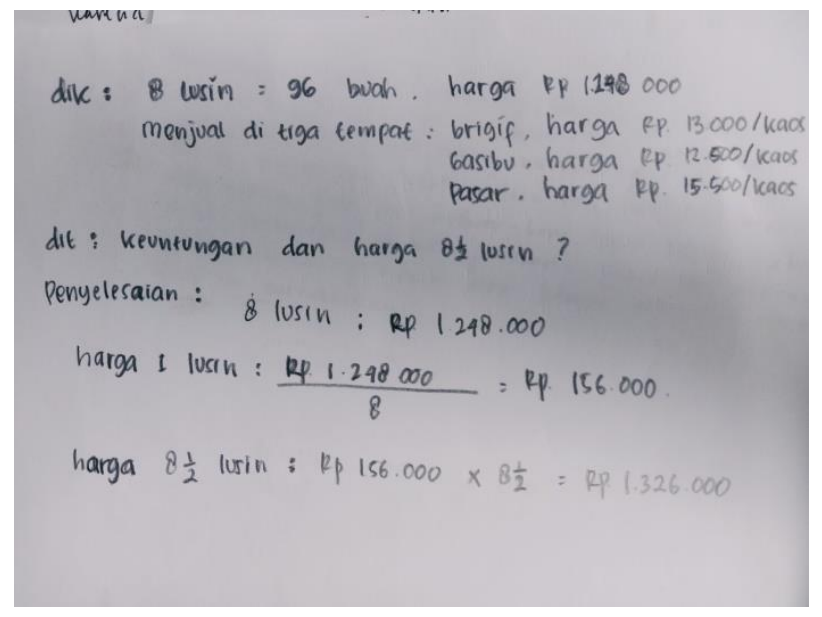

Gambar 3. Kesalahan Jawaban Siswa pada Tahap Transformasi

Pada gambar 3 terlihat bahwa siswa sudah mengerti dengan pertanyaan dan sudah memahami soal serta sudah dapat membuat model matematika. Akan tetapi pada tahapan kedua siswa nampaknya masih kebingungan yakni kebanyakan jawaban siswa tidak membagi jumlah kaos sebanyak 8 lusin menjadi tiga bagian . sehingga jawaban sisw menjadi kacau ke tahap selanjutnya. Maka dari itu siwa 
Analisis Kemampuan Pemecahan Masalah Matematis Siswa Smp Kelas VII Pada Materi Aritmetika Sosial, Rizky Restiani

yang menjawab salah pada tahp dua atau hanya dapat menjawab sampai tahap satu saja hanya memperoleh skor 1. Berdasarkan wawancara siswa memang mengalami kebingungan pada saat mengerjakan tahapan dua. Namun siswa ada keiginan untuk menjawab soal tersebut dan mencoba menjawab walau semampunya. Berdasarkan angket diperoleh informasi bahwa siswa kurang menyukai pelajaran matematika karena konsep yang ada pada matematika saling berkaitan, sehingga apabila tidak dapat memahami satu konsep maka akan sulit memahami konsep yang lainnya. Namun disisi lain siswa tetap berusaha menjawab soal matematika karena tidak ingin memperoleh nilai yang rendah.

\section{Analisis Kesalahan Jawaban Siswa pada Tahap Keterampilan Proses}

Banyak siswa yang melakukan kesalahan pada tahap keterampilan proses, berikut ditampilkan salah satu jawaban siswa yang salah pada tahapan ke tiga, sehingga memperoleh skor 2.

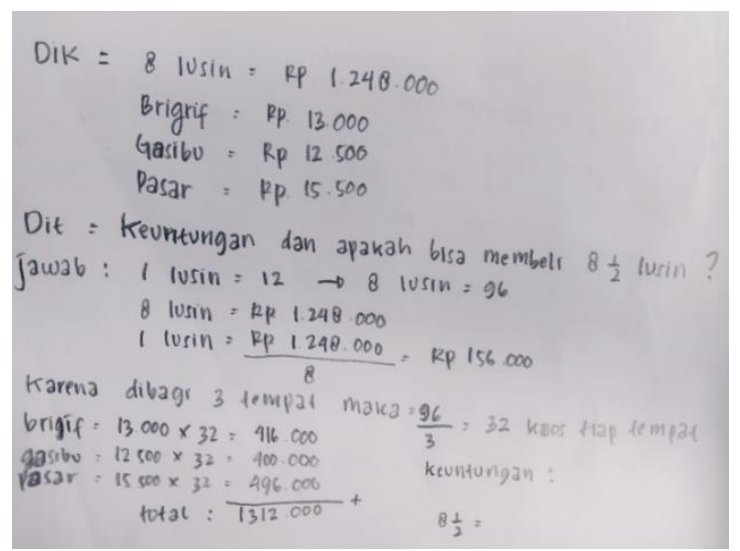

Gambar 4. Kesalahan Jawaban Siswa pada Tahap Keterampilan Proses (Melakukan penyelesaian)

Pada gambar 4 dapat dilihat bahwa siswa sudah mampu mengerjakan tahapan satu dan dua. Namun siswa belum mampu mengerjakan pada tahapan ke tiga. Yakni siswa merasa bingung sehingga sehingga tidak tahu bagaimana caranya menjawab apakah pedagang dapat membeli 8 1/2 lusin kaos atau tidak. Menurut angket yang diberikan pada siswa, ia tidak begitu menyenangi pelajaran matematika karena banyak konsep yang harus dipahami.

\section{Analisis Kesalahan Jawaban Siswa Pada Tahap Penyimpulan}

Makin banyak siswa yang melakukan kesalahan pada tahap terakhir yaitu tahap penyimpulan. Hal ini disebabkan karena banyak siswa yang melakukan kesalahan di tahap sebelumnya. Berikut dapat dilihat salah satu jawaban siswa yang menjawab salah pada tahap keempat sehingga hanya memperoleh skor 3. 


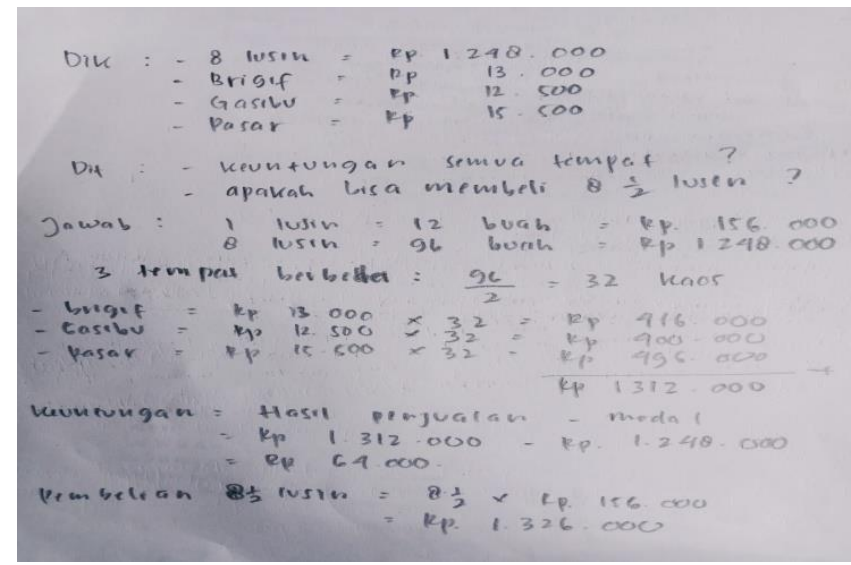

Gambar 5. Kesalahan jawaban siswa pada tahap penyimpulan dan memeriksa kembali jawaban

Pada gambar 4 dapat dilihat bahwa siswa sudah mampu mengerjakan tahap satu, dua dan tiga. Bahkan pada tahap keempat siswa juga sudah mampu mengerjakan soal dengan baik akan tetapi kebanyakan dari jawaban siswa tidak memakai kesimpulan padahal soal yang diberikan merupakan soal cerita. Menurut wawancara yang telah dilakukan kebanyakan dari siswa menyatakan bahwa mereka lupa menuliskan kesimpulan pada lembar jawaban mereka. Berdasarkan angket juga siswa memang menyukai pelajaran matematika dan menyebutkan bahwa soal yang diberikan lumayan mudah, tidak terlalu sulit. Materi yang mereka sukai juga salah satunya yaitu materi aritmatika sosial sangat sesuai dengan soal yang diberikan.

Berdasarkan analisis terhadap kesalahan-kesalahan jawaban siswa, sebagian besar siswa yang mengalami kesulitan dalam mengerjakan soal yang diberikan yaitu karena mereka kurang memahami materi aritmatika sosial dan juga tidak paham dengan soal-soal cerita matematiak. Selain itu siswa juga kurang teliti dalam mengerjkan soal dan terburu-buru ingin cepat selesai. Sehingga mereka tidak memeriksa kembali jawaban. Selain itu kebanyakan siswa tidak menyukai pelajaran matematika karena mereka beranggapan bahwa matematika itu menakutkan hal ini sejalan dengan farida (2015) kebanyakan siswa tidak paham dan kurang mengerti dalam mengerjakan soal cerita mereka kesulitan dalam memodelkan matematikanya. Dapat disimpulkan bahwa kemampuan Pemecahan masalah siswa kelas VII pada materi Aritmatika sosial tergolong rendah, mereka tidak terbiasa mengerjakan soal-soal pemecahan masalah, sehingga kesulitan dalam menyelesaikan soal. hal ini sejalan dengan hasil penelitian Akbar (2018) dimana kemampuan pemecahan masalah matematis siswa di jenjang yang lebih tinggi (SMA) juga masih tergolong rendah, dimana siswa tidak terbiasa mengerjakan soal-soal pemecahan masalah.

\section{KESIMPULAN}

Berdasarkan penelitian yang telah dilakukan kepada siswa kelas VII di salah satu SMPN Kabupaten Purwakarta bahwa kemampuan pemecahan masalah matematis siswa tersebut tergolong rendah. dari data yang didapat 36 siswa, disimpulkan bahwa kemampuan pemecahan masalah siswa masih tergolong 
rendah. Banyak siswa masih keliru dalam indikator memahami masalah, merencanakan penyelesaian, melaksanakan penyelesaian, dan memeriksa kembali jawaban. Hal tersebut disebabkan karena siswa masih belum terbiasa mengerjakan soal-soal pemecahan masalah sehingga siswa mendapatkan kesulitan dalam memahami setiap soal tersebut, siswa banyak yang keliru dalam melakukan perhitungan penyelesaian masalah, selain itu siswa rata-rata tidak memeriksa kembali jawaban yang telah dibuat.

\section{DAFTAR PUSTAKA}

Akbar, P., Hamid, A., Bernard, M., \& Sugandi, A. I. (2018). Analisis kemampuan pemecahan masalah dan disposisi matematik siswa kelas xi sma putra juang dalam materi peluang. Jurnal Cendekia: Jurnal Pendidikan Matematika, 2(1), 144-153.

Bernard, M., Nurmala, N., Mariam, S., \& Rustyani, N. (2018). Analisis Kemampuan Pemecahan Masalah Matematis Siswa SMP Kelas IX Pada Materi Bangun Datar. SJME (Supremum Journal of Mathematics Education), 2(2), 77-83.

Bernard, M., Akbar, P., Ansori, A., \& Filiestianto, G. (2019, October). Improve the ability of understanding mathematics and confidence of elementary school students with a contextual approach using VBA learning media for Microsoft Excel. In Journal of Physics: Conference Series (Vol. 1318, No. 1, p. 012035). IOP Publishing.

Bernard, M., Sumarna, A., Rolina, R., \& Akbar, P. (2019, October). Development of high school student work sheets using VBA for microsoft word trigonometry materials. In Journal of Physics: Conference Series (Vol. 1315, No. 1, p. 012031). IOP Publishing.

Bungsu, T. K., Vilardi, M., Akbar, P., \& Bernard, M. (2019). Pengaruh Kemandirian Belajar Terhadap Hasil Belajar Matematika Di Smkn 1 Cihampelas. Journal on Education, 1(2), 382-389.

Hendriana, H dan Soemarmo, U. (2014).Penilaian Pembelajaran Matematika. Bandung: PT. Refika Aditama.

Farida, N. (2015). Analisis kesalahan siswa SMP kelas VIII dalam menyelesaikan masalah soal cerita matematika. AKSIOMA: Jurnal Program Studi Pendidikan Matematika, 4(2).

Fitria, R. (2018). ANALISIS KEMAMPUAN PEMECAHAN MASALAH MATEMATIS SISWA PADA MATERI ARITMATIKA SOSIAL KELAS VII SMP DALAM PEMBELAJARAN MATEMATIKA. Jurnal Pendidikan Tambusai, 2(4), 786-792.

Hidayat, A., \& Irawan, I. (2017). Pengembangan Lks Berbasis Rme Dengan Pendekatan Problem Solving Untuk Memfasilitasi Kemampuan Pemecahan Masalah Matematis Siswa. Jurnal Cendekia: Jurnal Pendidikan Matematika, 1(2), 51-63. https://doi.org/10.31004/cendekia.v1i2.20

Insani, S. U., \& Akbar, P. (2019, October). Development of Open-Ended Based Mathematics Problem to Measure High-Level Thinking Ability. In Journal of Physics: Conference Series (Vol. 1315, No. 1, p. 012047). IOP Publishing.

Nuryana, Dede. Rosyana, T. (2019). Analisis kesalahan siswa smk dalam menyelesaikan soal pemecahan masalah matematik pada materi program linear. Jurnal Cendekia: Jurnal Pendidikan Matematika, 3(1), 11-20.

Putra, H. D., Thahiram, N. F., Ganiati, M., \& Nuryana, D. (2018). Kemampuan Pemecahan Masalah 
Matematis Siswa SMP pada Materi Bangun Ruang. JIPM (Jurnal Ilmiah Pendidikan Matematika), 6(2), 82. https://doi.org/10.25273/jipm.v6i2.2007

Rahmawati, N. S., Bernard, M., \& Akbar, P. (2019). Analisis Kemampuan Komunikasi Matematik Siswa Smk Pada Materi Sistem Persamaan Linier Dua Variabel (SPLDV). Journal on Education, $1(2), 344-352$.

Siswanto, R. D., Dadan, D., Akbar, P., \& Bernard, M. (2018). Penerapan Model Pembelajaran Kooperatif Tipe Auditorial, Intelectually, Repetition (Air) Untuk Meningkatkan Pemecahan Masalah Siswa Smk Kelas XI. Journal on Education, 1(1), 66-74.

Sugandi, A. I. (2013). Pengaruh Pembelajaran Berbasis Masalah dengan Setting Kooperatif Jigsaw terhadap Kemandirian Belajar Siswa SMA. Jurnal Ilmiah Program Studi Matematika STKIP Siliwangi Bandung, 2(2), 144-155.

Sugandi, A. I., \& Akbar, P. (2019). Efektivitas Penerapan Strategi React Terhadap Kemampuan Koneksi Matematis dan Self-Efficacy Siswa SMP. Jurnal Cendekia: Jurnal Pendidikan Matematika, 3(2), 431-436

Timutius, F., Apriliani, N. R., \& Bernard, M. (2018). Analisis Kesalahan Siswa Kelas IX-G di SMP Negeri 3 Cimahi dalam Menyelesaikan Soal Pemecahan Masalah Matematik pada Materi Lingkaran. JPMI (Jurnal Pembelajaran Matematika Inovatif), 1(3), 305-312.

Ulvah, S. (2016). Kemampuan Pemecahan Masalah Matematis Siswa Ditinjau Melalui Model Pembelajaran SAVI dan Konvensional. Jurnal Riset Pendidikan, 2(2), 142-153.

Widodo, S. A. (2013). Analisis kesalahan dalam pemecahan masalah divergensi tipe membuktikan pada mahasiswa matematika. Jurnal pendidikan dan pengajaran, 46(2 Juli). 